\title{
The Role of Leaves in Photocontrol of Flower Bud Abscission in Hibiscus rosa-sinensis L. 'Nairobi'
}

\author{
Uulke van Meeteren ${ }^{1}$ and Annie van Gelder \\ Department of Plant Sciences, Horticultural Production Chains Group, Wageningen University, \\ Marijkeweg 22, 6709 PG Wageningen, The Netherlands
}

\begin{abstract}
AdDitional INDEX words. hibiscus, red (far-red) light
Aвstract. When compared with exposure to darkness, exposing Hibiscus rosa-sinensis L. 'Nairobi' plants to red light (635 to $\left.685 \mathrm{~nm}, 2.9 \mu \mathrm{mol} \cdot \mathrm{m}^{-2} \cdot \mathrm{s}^{-1}\right)$ delayed flower bud abscission, while exposure to far-red light $\left(705\right.$ to $\left.755 \mathrm{~nm}, 1.7 \mu \mathrm{mol} \cdot \mathrm{m}^{-2} \cdot \mathrm{s}^{-1}\right)$ accelerated this process. Flower bud abscission in response to light quality appears to be controlled partly by the presence of leaves. The delay of bud abscission was positively correlated to the number of leaves being exposed to red light. Excluding the flower buds from exposure to red or far-red light, while exposing the remaining parts of the plants to these light conditions, did not influence the effects of the light exposure on bud abscission. Exposing only the buds to red light by the use of red light-emitting diodes $\left(0.8 \mu \mathrm{mol} \cdot \mathrm{m}^{-2} \cdot \mathrm{s}^{-1}\right)$ did not prevent dark-induced flower bud abscission. Exposing the whole plants, darkness or far-red light could only induce flower bud abscission when leaves were present; bud abscission was totally absent when all leaves were removed. To prevent flower bud abscission, leaves had to be removed before, or at the start of, the far-red light treatment. These results suggest that in darkness or far-red light, a flower bud abscission-promoting signal from the leaves may be involved.
\end{abstract}

Abscission of flowers and/or flower buds during postharvest handling is a common problem in a wide range of floricultural crops (Cameron and Reid, 1983; Reid and Goszczynska, 1985; Thaxton et al., 1988). However, the mechanisms of abscission have been studied most extensively with leaves. In a study using explants from three clones of a Begonia davisii hybrid, Hänisch ten Cate et al. (1975) suggested similarities between reproductive structure abscission and leaf abscission.

After production, flowering potted plants and cut flowers are stored or transported in darkness or at low light levels. Abscission of flowers and/or flower buds (Craker and Decoteau, 1984; Force et al., 1988; Van Meeteren and De Proft, 1982) as well as leaves (Decoteau and Craker, 1984, 1987) is controlled or partly controlled by light. It is concluded that phytochrome is the light receptor responsible for controlling leaf abscission in Phaseolus aureus Roxb. (Curtis, 1978), Vigna radiata (L.) Wilczek (Decoteau and Craker, 1987) and Coleus blumei Benth. (Craker et al., 1987), based on the inhibition and promotion, respectively, by a low photon flux of red and far-red light, and the red/far-red reversibility. Darkinduced flower bud abscission in Hibiscus rosa-sinensis L. was reduced by applying red light ( 635 to $685 \mathrm{~nm}, 3.3 \mu \mathrm{mol} \cdot \mathrm{m}^{-2} \cdot \mathrm{s}^{-1}$ ) continuously as well as short red light pulses during darkness (red/dark 30/45 s) to the plants (Van Lieburg et al., 1990). The effect of red light pulses on preventing flower bud abscission was reversed by a short exposure of the plants to far-red light (705 to $755 \mathrm{~nm}, 7.5 \mu \mathrm{mol} \cdot \mathrm{m}^{-2} \cdot \mathrm{s}^{-1}$; red/far-red $\left.30 / 45 \mathrm{~s}\right)$, indicating the involvement of a low fluence rate reaction of phytochrome (Van Lieburg et al., 1990).

Flower bud abscission induced by darkness or low light intensity is mediated through ethylene produced by the flower bud, as was shown for the lily hybrid (Lilium L.) 'Enchantment' (Van Meeteren and De Proft, 1982), Capsicum annиum L. (Wien et al., 1989) and Hibiscus rosa-sinensis L. (Van Meeteren and Van Gelder, 1995). The photocontrol of leaf abscission appeared

Received for publication 30 Apr. 1999. Accepted for publication 27 Sept. 1999. The cost of publishing this paper was defrayed in part by the payment of page charges. Under postal regulations, this paper therefore must be hereby marked advertisement solely to indicate this fact.

${ }^{1}$ To whom correspondence should be addressed; fax: +31 317 484709, e-mail uulke.vanmeeteren@users.tbpt.wau.nl. not to be mediated by ethylene (Decoteau and Craker, 1987), indicating differences in the mechanisms controlling flower and leaf abscission. The site of perception for photocontrol of leaf abscission is apparently located in the leaf blades (Decoteau and Craker, 1984). It has been hypothesized that this is a consequence of a light regulation of endogenous auxin transported from the leaf blade to the abscission zone in the leaf petiole (Mao et al., 1989).

The site of perception for the photocontrol of flower bud abscission is currently unknown. Because auxins applied to explants consisting of a pedicel and the attached flower bud, can prevent ethylene-induced flower bud abscission in Hibiscus rosa-sinensis L. (Van Meeteren and Van Gelder, 1995), it is possible that phytochrome-controlled auxin transport from the leaves to the flower buds is involved in the photocontrol of flower bud abscission. In this case, it is reasonable to postulate that the site of perception for the photocontrol of flower bud abscission is located in the leaves. Moreover, leaf removal should induce flower bud abscission. This paper presents experiments that investigated the role of leaves in photocontrol of flower bud abscission in Hibiscus rosa-sinensis L.

\section{Material and Methods}

A preliminary abscission experiment with four cultivars of Hibiscus rosa-sinensis L. ('Nairobi', 'Paramaribo', 'Rosali', and 'Sinensis') showed that they all react in the same way to a period of darkness. Abscission was hastened by exposure of the plants to far-red light, while abscission could be prevented by low intensity red light. For all these cultivars, abscission mainly occurred in less developed buds (bud length $<2.5 \mathrm{~cm}$ ) as also described by Force et al. (1988) for Hibiscus rosa-sinensis L. 'Brilliant Red' after dark storage. Therefore, 'Nairobi' was chosen as a representative cultivar for the experiments described in this paper.

Plant material. Rooted softwood cuttings of Hibiscus rosasinensis L. 'Nairobi' were planted during the period 1 Mar. to 1 Apr. 1994 in 0.9-L (14-cm-diameter) plastic pots containing a commercial potting soil [15\% clay, $20 \%$ peatmoss, $25 \%$ peat mold, $40 \%$ upgraded black peat (by volume)]. Plants were grown in a greenhouse with setpoints for heating of $20{ }^{\circ} \mathrm{C}($ day $) / 19{ }^{\circ} \mathrm{C}$ 
(night), venting at $22{ }^{\circ} \mathrm{C}$ (day) $/ 21^{\circ} \mathrm{C}$ (night). Average temperature during the entire period was $21.3^{\circ} \mathrm{C}$, with a minimum of 17 to $19^{\circ} \mathrm{C}$ and maximum of 26 to $39^{\circ} \mathrm{C}$ (April to September). Highpressure sodium lamps provided supplementary lighting beginning in October, from 0700 to $2000 \mathrm{HR}$ [additional 50 to 60 $\mu \mathrm{mol} \cdot \mathrm{m}^{-2} \cdot \mathrm{s}^{-1}$ photosynthetic photon flux (PPF) on the upper leaves]. Average natural irradiance level in the greenhouse was $19.4,25.0,10.5$, and $4.0 \mathrm{~mol} \cdot \mathrm{m}^{-2} \cdot \mathrm{d}^{-1}$ photosynthetically active radiation (PAR) in April to May, June to August, September to October and November, respectively. However, it varied greatly between individual days (from 3.4 to $20.0 \mathrm{~mol} \cdot \mathrm{m}^{-2} \cdot \mathrm{d}^{-1}$ in September; from 0.7 to $9.3 \mathrm{~mol} \cdot \mathrm{m}^{-2} \cdot \mathrm{d}^{-1}$ in November). Plants were grown for a total of 5 to 7 months before starting the abscission experiments. Six experiments were carried out from 1 Sept. to $1 \mathrm{Dec}$. 1994. During this period, average greenhouse day temperature was 21.9, 20.8, and 20.0 in September, October, and November, respectively.

Two types of plants were used: 1) plants grown according to the standard practices of commercial growers (commercial plants) and 2) single-stemmed plants. Commercial plants were grown in the following way: About 2 months before the plants were used in an abscission experiment, their terminal meristems were removed to promote lateral growth of three to four branches. To obtain compact plants, chloromequat (2-chloroethyl trimethylammonium chloride) was applied at $117 \mathrm{mg} \cdot \mathrm{L}^{-1}$ as a foliar spray three times at 2-week intervals, starting one week after pinching. Because photocontrolled flower bud abscission in Hibiscus primarily occurs in less developed flower buds (Force et al., 1988), commercial plants, which had at least three flower buds with a bud length between 5 and $10 \mathrm{~mm}$ were used. Two of these buds were marked and used for observing abscission. Because the number of mature buds influences the number of abscising buds (Force et al., 1988), all flower buds whose inner sepals had started to open and buds in more advanced developmental stages were removed at the start of the experiment. All other, nonmarked buds were neither treated nor observed. Single-stemmed plants were obtained by pruning the plants at the fourth basal node when the main shoot of most plants had formed about eight full-grown leaves. During the cultivation period of the single-stemmed plants, all lateral shoots except the uppermost (at the fourth leaf) were removed. This shoot was pruned at the second basal node as soon as its eighth leaf had fully expanded. Again all lateral shoots except the uppermost were removed. Single-stemmed plants were not treated with any growth retardant. Plants with a flower bud measuring 6 to $9 \mathrm{~mm}$ were used, and all other flowers and buds were removed.

Abscission of the buds was considered to have occurred when flower buds abscised upon a gentle touch. Abscission occurs at the upper abscission zone in the pedicel about $3 \mathrm{~mm}$ from the bud.

EXPERIMENT 1: COVERING FLOWER BUDS DURING EXPOSURE OF INTACT PLANTS TO VARIOUS LIGHT CONDITIONS. Commercial plants were exposed to the various light conditions until the designated flower buds (two buds per plant) had abscised. Darkness, red, or far-red light conditions $\left(24 \mathrm{~h} \cdot \mathrm{d}^{-1}\right)$ were imposed by placing plants in controlled environment chambers at $20^{\circ} \mathrm{C}$ and $60 \%$ relative humidity (one chamber for each light condition). In the dark treatments, the only exposure to light was during observations and watering, which was done with green safe light (TLD36W/17 Green, Philips, Eindhoven, The Netherlands). Twenty commercial plants each were exposed to either red light from TL $36 \mathrm{~W} 15$ (Philips, Eindhoven, The Netherlands), $2.9 \mu \mathrm{mol} \cdot \mathrm{m}^{-2} \cdot \mathrm{s}^{-1}$ (635 to $685 \mathrm{~nm}$ range); far-red light from 'Voltcraft Schwarzlicht' lamps
(Nijssen Light Division BV, Wageningen, The Netherlands), 1.7 $\mu \mathrm{mol} \cdot \mathrm{m}^{-2} \cdot \mathrm{s}^{-1}$ ( 705 to $755 \mathrm{~nm}$ range); or to darkness. Irradiance was measured with a LI-1800 spectroradiometer (LI-COR, Lincoln, Nebr.), scanning from 300 to $1100 \mathrm{~nm}$. From half the plants under each light condition, the two designated buds were wrapped by aluminum foil to exclude the buds from red or far-red light while exposing the plants to these light conditions. The wrapped buds in darkness served as a control on any possible stress effect of the wrapping by aluminum foil (e.g. mechanical injury or pressure, change of atmospheric composition) on abscission. Within a light treatment there was a completely randomized design. Each treatment had 10 experimental units (one plant in a pot). By daily recording of flower bud abscission, the number of days till abscission of each designated bud was recorded. The averaged time of the two buds from each plant was used for statistical analysis.

EXPERIMENT 2: EXPLANTS. Explants consisted of a pedicel and the attached flower bud (bud length 6 to $9 \mathrm{~mm}$ ). They were cut from the commercial plants, $10 \mathrm{~mm}$ below the upper abscission zone; one explant per plant. The cut surface of the pedicels was inserted into $1 \%$ water-agar blocks (Bacto-Agar, Difco, Detroit, Mich.) in glass vials, each explant in a separate vial. Explants were exposed to darkness, red light, or far-red light conditions as described for Expt. 1. Each light treatment contained 10 experimental units (explants). Time till abscission of each bud was recorded during a 4-d period, at that time all buds had abscised.

EXPERIMENT 3: EXPOSURE OF ATTACHED FLOWER BUDS TO RED LIGHT. Twenty commercial plants were placed in darkness. Two flower buds attached to half of the plants received irradiance from red light-emitting diodes (LEDs), $0.8 \mu \mathrm{mol} \cdot \mathrm{m}^{-2} \cdot \mathrm{s}^{-1}$ (635 to 685 $\mathrm{nm}$ range). Each LED was mounted in the upper end of a PVC tube (diameter $1.3 \mathrm{~cm}$, length $16.5 \mathrm{~cm}$ ). By the use of clamps fixed to unipods, the lower end of the PVC tube was positioned around a flower bud. After enclosing a flower bud in the tube, it was sealed by cotton plugs to prevent irradiance on the leaves. There was a completely randomized design. Each treatment had 10 experimental units (one plant in a pot). Flower bud abscission was recorded daily; for the buds exposed to the red light, the PVC tubes were carefully taken away during observation. The number of days till abscission of each designated bud was recorded. The averaged time of the two buds from one plant was used for statistical analysis.

EXPERIMENT 4: COVERING LEAVES. To investigate the role of leaves, 40 commercial plants were placed under the red light conditions described for Expt. 1. From these plants, various numbers of leaves were covered by aluminum foil to exclude them from irradiance: a) all leaves were enclosed by pieces of aluminum foil; b) all leaves except the three uppermost fullgrown leaves of each branch, were enclosed by pieces of aluminum foil; c) the basal third of the leaves were enclosed by aluminum foil; d) no leaves were covered. The average plant height was $24 \pm 3 \mathrm{~cm}$. This experiment was a completely randomized design with 10 experimental units (one plant in a pot) for each treatment. Observed is the length of time till the first of the two designated flower buds abscised (survival time). The experiment was terminated after $22 \mathrm{~d}$.

Experiment 5: LeAF Removal. Thirty-six single-stemmed plants were placed under each of the three light conditions as described for Expt. 1. Under each light condition, three leaf removal treatments were given to the plants: all leaves were removed at the beginning of the experiment, all leaves except the two uppermost full-grown leaves were removed, or no leaves 
were removed. Leaves were removed by cutting the petioles. The plants had 15 to 20 leaves before leaf removal. Within each light condition there was a randomized complete block design with four blocks, three leaf removal treatments/block, three experimental units (a plant with one bud)/treatment in each block. The experiment was terminated after $16 \mathrm{~d}$; at that time buds had abscised or had reached anthesis. Time to flower bud abscission was recorded daily.

EXPERIMENT 6: LEAF REMOVAL UNDER FAR-RED IRRADIANCE. Thirty single-stemmed plants were placed under far-red light conditions. All leaves were removed at the beginning, or one, two, or three $d$ after the start of the far-red light exposure, or not removed at all. Leaves were removed by cutting the petioles. The plants had 15 to 20 leaves before leaf removal. There was a randomized complete block design with two blocks, fifteen plants/block, three experimental units (a plant with one bud)/ treatment in each block. Observed is time till a flower bud abscised (survival time). The experiment was terminated after 7 $\mathrm{d}$. Then, the same experiment was repeated, treating the second experiment as two additional blocks for statistical analysis.

Statistical analysis. Flower bud abscission is a critical event, which can happen or not. When it happens, it can occur at different times. When all buds abscise, it is possible to analyze the mean time till abscission occurred. In that case analysis of variance followed by a $t$ test or an HSD test is possible. Data in Expts. 1 and 3 were statistically analyzed by analysis of variance using the GENSTAT 5 program (Rothamsted, U.K.), followed by mean separation according to Tukey's HSD test. In Expt. 1, the residual mean square of the light regime $\times$ covering buds stratum was also used for testing the significance of the light regime effect. Because there are no replicates of the growth chambers with the same light conditions, any other environmental conditions associated with the growth chamber might have influenced the treatment effect. However, the aim of this experiment was to test any interaction between covering buds $\times$ light regime (growth chamber). As described in the introduction, effects of darkness, red light and far-red light on flower bud abscission of hibiscus are known. Testing of the light regime effect was included to be sure that plants without covered buds reacted like reported before. In some experiments, some of the treatments resulted in preventing abscission within a reasonable time span or before anthesis. Mean time till abscission cannot be calculated in those cases. Survival analysis is concerned with the time to occurrence of a critical event of interest (survival time) (Kleinbaum, 1995). The event need not be adverse. Survival analysis techniques are unique in that they use information from cases that have not experienced the terminal event during the time of observation (censored data). Data in Expts. 4 and 6 were analyzed by survival analysis using the Kaplan-Meier procedure of SPSS Advanced Statistics 7.5 (SPSS Inc., Chicago) with right censored data. Of this procedure, the log-rank (or Mantel-Cox) and Breslow (or generalized Wilcoxon) test of statistical significance were used. Because both tests gave comparable results, only the results of the log-rank test are presented. In Expt. 5, survival analysis was performed only within the far-red treatment to compare the three leaf removal treatments.

\section{Results}

Although the aluminum covering of flower buds (Expt. 1) would have changed the microclimate around and the atmosphere inside the covering, the light treatments affected the abscission time to the same extent, regardless of whether the flower buds were covered by aluminum foil or were exposed to the light sources (Table 1). Compared to darkness, exposing plants to red light delayed flower bud abscission, while far-red light hastened this process.

Red light did not prevent or delay flower bud abscission of explants, consisting of a pedicel and the attached flower bud (Expt. 2, data not presented). In darkness as well as in red light, $100 \%$ of the buds had abscised by day four. Explants exposed to far-red light showed $100 \%$ abscission by day three of the experiment. Also, abscission of buds from plants placed in darkness was not significantly inhibited by exposing only the buds to red light (Expt. 3): flower buds abscised after $7.3 \pm 0.5 \mathrm{~d}$ from plants placed in darkness, and after $7.9 \pm 0.5 \mathrm{~d}$ when flower buds were irradiated by red light-emitting diodes while the plants themselves were kept in darkness.

When plants were exposed to red light (Expt. 4), the delay of flower bud abscission was positively related to the increasing number of leaves being exposed to red light (Fig. 1). This indicates that the amount of leaf area exposed to red light is an important factor that delays bud abscission.

Removal of leaves before light treatments began (Expt. 5) drastically diminished the occurrence and rate of flower bud abscission (Table 2). When all leaves were removed at the beginning of exposing plants to darkness, red, or far-red light, no flower bud abscission occurred; all buds reached anthesis after 14 to $16 \mathrm{~d}$. When two leaves were left on the plants, only far-red light induced bud abscission. Under far-red light, abscission of the flower buds on intact plants occurred in about half the time as that in plants with only two leaves.

The time the plants were exposed to far-red light before their leaves were removed (Expt. 6) influenced the number of abscised flower buds (Fig. 2). Removal at the beginning of the far-red light treatment totally prevented abscission; removal after $1 \mathrm{~d}$ of farred light exposure delayed abscission, resulting in 58\% abscission after $7 \mathrm{~d}$ under far-red light. Compared to the intact plant ( $100 \%$ abscission), leaf removal after 2 to $3 \mathrm{~d}$ had no effect on preventing or delaying flower bud abscission under far-red light.

\section{Discussion}

Red and far-red light treatments of Hibiscus plants affected

Table 1. Effect of covering flower buds on time to flower bud abscission, during exposure of intact plants to various light regimes (Expt. 1). Buds were wrapped with aluminum foil at the start of the light treatment.

\begin{tabular}{|c|c|c|}
\hline \multirow[b]{2}{*}{ Light regime } & \multicolumn{2}{|c|}{$\begin{array}{l}\text { Time to flower } \\
\text { bud abscission }{ }^{\mathrm{z}}(\mathrm{d})\end{array}$} \\
\hline & Buds uncovered & Buds covered \\
\hline Darkness & $5.3 \pm 0.5$ & $5.0 \pm 0.4$ \\
\hline Red light & $9.8 \pm 0.7$ & $10.1 \pm 0.6$ \\
\hline Far-red light & $2.8 \pm 0.2$ & $3.0 \pm 0.3$ \\
\hline \multicolumn{3}{|l|}{ Analysis of variance } \\
\hline Light regime & \multicolumn{2}{|c|}{$\mathrm{NA}^{\mathrm{y}}$} \\
\hline Covering buds & \multicolumn{2}{|c|}{ NS } \\
\hline Light regime $\times$ covering bud & \multicolumn{2}{|c|}{ NS } \\
\hline
\end{tabular}




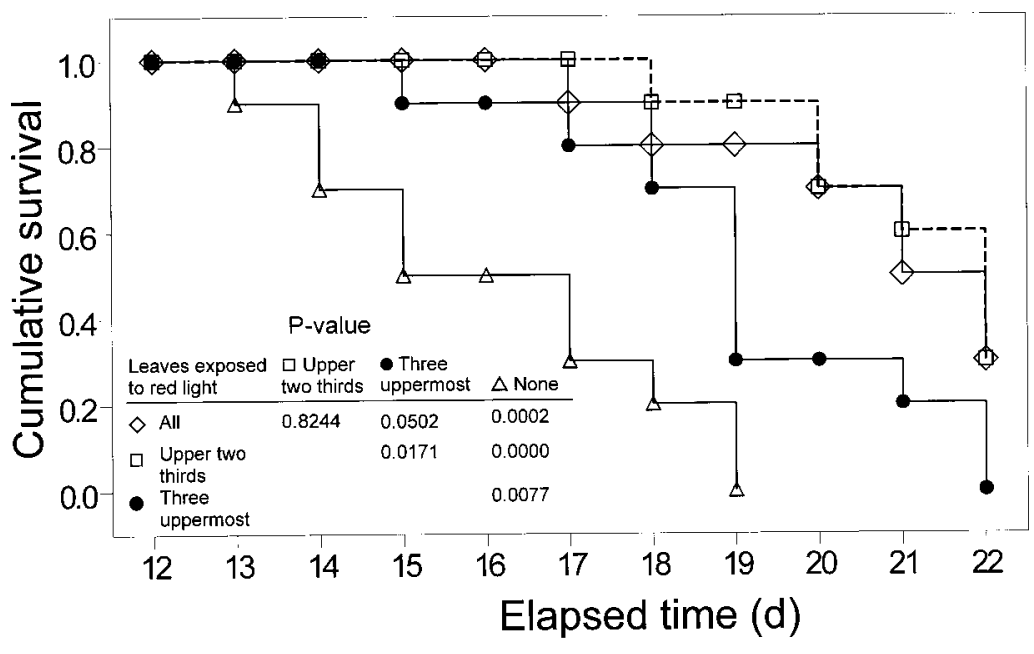

Fig. 1. Effect of exposing various number of leaves to red light on survival (no abscission) of flower buds (Expt. 4). Only the flower buds (none), the three uppermost full-grown leaves and flower buds of each branch (three uppermost), the upper two-thirds of all the leaves and flower buds (upper two-thirds), or all leaves and flower buds (all) were exposed to red light by placing plants under red light while different plant parts were enclosed by pieces of aluminum foil. Cumulative survival as fraction of 10 commercial plants; abscission of the first of two flower buds on each plant observed as critical event.

flower bud abscission as reported previously (Van Lieburg et al., 1990). However, exposing only buds to red light by the use of LEDs, did not prevent dark-induced flower bud abscission, indicating that other plant parts play an important role in lightcontrolled flower bud abscission. It is unlikely that the lack of an abscission inhibiting effect by the use of the LEDs was due to changes in the gaseous atmosphere around or inside the flower bud as result of the tubes around the buds, because enclosing flower buds by aluminum foil did not affect abscission in any way. The importance of other plant parts to light control of flower bud abscission was also indicated by the finding that flower bud explants showed $100 \%$ bud abscission, irrespective of light treatment. For the Asiatic lily hybrid (Lilium L.) 'Enchantment', Van Meeteren and De Proft (1982) concluded that, under white light, some factor was formed by plant parts other than the flower bud, which prevented bud abscission by suppressing ethylene evolution from the flower buds. Excision of the lily buds induced an increase of the ethylene evolution by the buds under white light conditions. Flower bud abscission of Hibiscus rosa-sinensis L. is also mediated by ethylene (Thaxton et al., 1988; Van Meeteren and Van Gelder, 1995) produced by the flower bud (Van Meeteren and Van Gelder, 1995). Abscission of Hibiscus flower bud explants was not observed when the explants were placed in a solution of aminoethoxyvinylglycine (AVG), an inhibitor of ethylene biosynthesis, indicating that the abscission may not be due to the absence of water uptake by the explants (unpublished results).

Excluding buds from red or far-red light while exposing the plants to these light conditions, did not influence the effects of the light treatment on bud abscission, suggesting that exposure of the leaves to the various light sources is of much more importance than exposing the flower buds to the same conditions. This conclusion was supported by the negative relationship between the number of leaves exposed to red light and the occurrence of flower bud abscission (Fig. 1). Decoteau and Craker (1984) demonstrated that inhibition of leaf abscission in Vigna radiata (L.) Wilczek by red light requires the movement of a translocatable substance from the leaf tissue to the abscission zone.

Mao et al. (1989) suggested that a phytochrome-mediated light regulation of the endogenous auxin level in the leaf is the mechanism that controls leaf abscission in Coleus blumei Benth. Because auxins applied to isolated flower buds can prevent flower bud abscission in Hibiscus (Van Meeteren and Van Gelder, 1995), it was suggested that phytochrome-controlled auxin transport from the leaves is also involved in the photocontrol of flower bud abscission. Therefore, in the current study, Expt. 5, all leaves were removed to prevent auxin transport from leaves to the flower buds. Contrary to expectation, flower bud abscission was totally absent under far-red light and dark conditions when the leaves were removed (Table 2). When only two leaves remained, darkness still did not induce flower bud abscission. In contrast to leaf abscission, this implies that flower bud abscission in darkness or far-red light may be the result of an abscission-promoting signal transported from the leaves to the flower buds, and is not a consequence of the absence of an abscission-inhibiting substance from the leaves. This is in agreement with the finding that far-red light-induced abscission took about twice as long when only two leaves remained as for plants with all their leaves. It is unlikely that abscission is inhibited by leaf removal due to a shortage of assimilates (energy), since excised flower buds did show abscission. Moreover, only two of the initial 15 to 20 leaves were necessary to inhibit flower bud abscission significantly. Although it took 2 to $4 \mathrm{~d}$ before flower bud abscission started under far-red light conditions, leaves had to be removed before the far-red light period started in order to totally prevent flower bud abscission (Fig. 2). Therefore, the signal from the leaves appears to be transported quickly after far-red light exposure began. It is the expression of the abscission that took several days.

Table 2. Effect of leaf removal on flower bud abscission of plants exposed to various light conditions (Expt. 5). Immediately before the light treatments began, all leaves were removed, the leaves except the two uppermost full-grown leaves were removed, or no leaves were removed. Plants had 15 to 20 leaves before leaf removal.

\begin{tabular}{|c|c|c|c|}
\hline \multirow[b]{2}{*}{ Light treatment } & \multicolumn{3}{|c|}{$\begin{array}{l}\text { Time to flower } \\
\text { bud abscission }^{\mathrm{z}}(\mathrm{d})\end{array}$} \\
\hline & All leaves removed & Two leaves left & No leaves removed \\
\hline Red light & Not $\mathrm{AB}^{\mathrm{y}}$ & Not AB & Not AB \\
\hline Darkness & Not AB & Not AB & $10.3 \pm 0.6$ \\
\hline Far-red light & Not $A B A^{x}$ & $6.3 \pm 0.6 \mathrm{~B}$ & $3.5 \pm 0.3 \mathrm{C}$ \\
\hline
\end{tabular}

${ }^{2}$ Time after start of the light treatment; mean \pm SE of the mean of 12 single-stemmed plants.

${ }^{y}$ Not $\mathrm{AB}=$ flower buds did not abscise, all reached anthesis after 14 to $16 \mathrm{~d}$. ${ }^{\mathrm{x}}$ Numbers followed by a different letter are significantly different at $P$ $\leq 0.001$ level, log-rank survival analysis. 


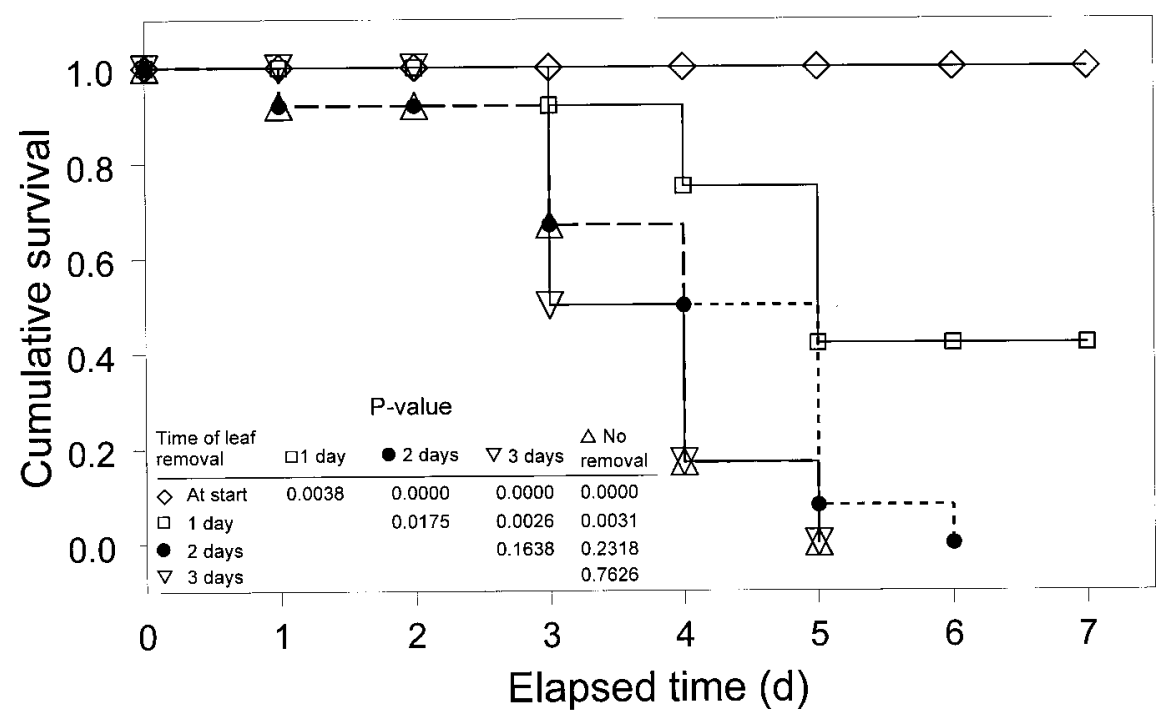

Fig. 2. Effect of time of leave removal, while plants were exposed to far-red light, on survival (no abscission) of flower buds (Expt. 6). Leaves were removed at the beginning (At start), 1 d, $2 \mathrm{~d}$, or $3 \mathrm{~d}$ after the start of the far-red light exposure or not at all (No removal). Cumulative survival as fraction of 12 single-stemmed plants; abscission of the flower bud observed as critical event.

\section{Literature Cited}

Cameron, A.C. and M.S. Reid. 1983. Use of silver thiosulfate to prevent flower abscission from potted plants. Scientia Hort. 19:373-378.

Craker, L.E. and D.R. Decoteau. 1984. Light control of flower abscission in snapdragons. HortScience 19:77.

Craker, L.E., S.Y. Zhao, and D.R. Decoteau. 1987. Abscission: Response to red and far-red light. J. Expt. Bot. 38:883-888.

Curtis, R.W. 1978. Participation of phytochrome in the light inhibition of malformin-induced abscission. Plant Cell Physiol. 19:289-297.

Decoteau, D.R. and L.E. Craker. 1984. Abscission: Characterization of light control. Plant Physiol. 75:87-89.

Decoteau, D.R. and L.E. Craker. 1987. Abscission: Ethylene and light control. Plant Physiol. 83:970-972.

Force, A.R., K.A. Lawton, and W.R. Woodson. 1988. Dark-induced abscission of hibiscus flower buds. HortScience 23:592-593.

Hänisch ten Cate, Ch., J. Berghoef, A.M.H. van der Hoorn, and J. Bruinsma. 1975. Hormonal regulation of pedicel abscission in Begonia flower buds. Physiol. Plant. 33:280-284.

Kleinbaum, D.G. 1995. Survival analysis. Springer, New York.

Mao, Z., L.E. Craker, and D.R. Decoteau. 1989. Abscission in Coleus: Light and phytohormone control. J. Expt. Bot. 220:1273-1277.

Reid, M.S. and D.M. Goszczynska. 1985. Growth regulators and abscission in ornamentals. Acta Hort. 167:57-68.

Thaxton, D.R., J.W. Kelly, and J.J. Frett. 1988. Control of Hibiscus rosasinensis L. bud abscission during shipping. Scientia Hort. 34:131-137.

Van Lieburg, M.J., W.G. van Doorn, and H. van Gelder. 1990. Prevention of phytochrome related postharvest loss of quality in ornamentals through red light emitted by diodes. Acta Hort. 272:347-351.

Van Meeteren, U. and M. de Proft. 1982. Inhibition of flower bud abscission and ethylene evolution by light and silver thiosulphate in Lilium. Physiol. Plant. 56:236-240.

Van Meeteren, U. and H. van Gelder. 1995. Role of flower buds in flower bud abscission in Hibiscus. Acta Hort. 405:284-289.

Wien, H.C., A.D. Turner, and S.F. Yang. 1989. Hormonal basis for low light intensity-induced flower bud abscission of pepper. J. Amer. Soc. Hort. Sci. 114:981-985. 